DOI: http://doi.org/10.31617/k.knute.2019-03-19.15

\title{
СОЦІАЛЬНА РЕКЛАМА: ІНТЕРАКТИВНІ КАМПАНІЇ
}

\author{
Аліханова I.T. \\ студентка магістратури \\ кафедра журналістики та реклами \\ Київський національний торговельно-економічний університет, \\ Україна
}

Ключові слова: соціальна реклама, інтерактивність, соціальні кампанії.

Keywords: social advertising, interativity, social campaigns.

Соціальна реклама сьогодні є одним із інструментів формування громадської думки, моделей поведінки та соціальної відповідальності кожного індивіда. Нажаль, в Україні, незважаючи на значну кількість соціальних проблем, соціальна реклама використовує застарілі носії та ще не досягла такого рівня зацікавленості серед громадян та державних структур [1]. Проте як у розвинутих країнах соціальна реклама, в тому числі за допомогою інтерактивних засобів, перетворилась на потужний механізм, здатний вирішувати складні суспільні проблеми.

Згідно Закону України «Про рекламу» надається таке визначення поняттю: «Соціальна реклама - інформація будь-якого виду, розповсюджена в будь-якій формі, яка спрямована на досягнення суспільно корисних цілей, популяризацію загальнолюдських цінностей $i$ розповсюдження якої не має на меті отримання прибутку» [3]. Слід відзначити, що праць, присвячених теорії та методології соціальної реклами в Україні, обмаль. Але проблематика соціальної реклами останніми роками часто розглядається на сторінках періодичних видань i в інтернеті. Серед відомих дослідників аспектів функціонування соціальної реклами слід відзначити Н.В. Старих, Л.М. Федотову, С.О. Селіверстова, Г.Г. Ніколайшвілі та ін. Крім наукових досліджень, соціальна реклама стає предметом обговорення на різних конференціях i семінарах, у даному напрямі проводяться конкурси і фестивалі.

3 метою знаходження тематики та нових засобів використання соціальної реклами в Україні, розглянемо приклади інтерактивної соціальної реклами в зарубіжних країнах. Австралія показує своїм прикладом вдале застосування digital-білбордів як поєднання нових технологій 3 інтерактивністю. Так агентства «GPY\&R Melbourne» та «JCDecaux» провели соціальну кампанію «Wait with a Mate» («Очікуйте 3 другом»): на вокзалі був встановлений digital-білборд - інтерактивний 
білборд із вбудованим сенсором. Люди могли кинути віртуальний м'яч псу, який у свою чергу повертав реальний тенісний м'яч 3 надписом, що запрошував взяти тварину з притулку [4].

У Фінляндії рекламне агентство «Hasan \& partners» paзом 3 некомерційною організацією по захисту прав дітей «Plan Finland» використали інтерактивні екрани для того, щоб подякувати донорам. Для цього агентство попросило дітей розповісти про свої мрії, і розмістило інформацію про них на digital-екрані в одному з найбільших торгових центрів Фінляндії. Коли бажаючі жертвували гроші, активувався датчик камери, яка знімала донорів, а зображення потім демонструвалося на екрані рекламної конструкції [5].

$\mathrm{y}$ шведському метро встановили інтерактивний лайтбокс is зображенням дівчини, волосся якої розвівав вітер, коли на станцію прибував потяг. Фінал неочікуваний - дівчина залишається без волосся. Реклама належить «Дитячому фонду боротьби 3 раком» («Barncancerfonden»), який закликає звернути увагу на проблему дитячого раку і внести пожертвування на боротьбу з нею [6].

Отже, враховуючи світовий практичний досвід, можна удосконалювати соціальну рекламу в Україні використовуючи інтерактивні засоби. III роль може бути найбільш оптимізованою завдяки розумінню того, що формулювань цінностей слід чекати не від держави і державних органів, а виявляти ініціативу некомерційним організаціям. Також важливим фактором є готовність населення до вирішення проблем, що виникають у ньому особисто та суспільстві загалом, та освітлюються соціальною рекламою.

\section{Список використаних джерел}

1. Горбенко Г. В. Соціальна реклама та соціальні процеси в сучасному суспільстві: взаємозв'язок і взаємовпливи / Г. В. Горбенко // Бібліотекознавство. Документознавство. Інформологія. - 2013. № 4. - C. 56-59. - Режим доступу : http://nbuv.gov.ua/UJRN/ bdi_2013_4_12

2. Лютова Д. Мировая социальная реклама. [Електронний ресурс]. Режим доступу : http://1 soc.ru/. - Загол. з екрана.

3. Про рекламу : Закон України [Електронний ресурс]. - Режим доступу : http://zakon3.rada.gov.ua/laws/show/270/96-вp. - Загол. 3 екрана.

4. Соціальна реклама [Електронний ресурс]. - Режим доступу : http://www.2social.info/ - Загол. з екрана. 
5. Out of home [Електронний ресурс]. - Режим доступу : http://old.outof-home.ua/sobitia/finskaya-interaktivnaya-socialnaya-reklama-poblago darila-donorov

6. Wonder [Електронний peсурс]. - Режим доступу : https://www.wonderzine.com/wonderzine/life/news/202123-a-hairraising-message

DOI: http://doi.org/10.31617/k.knute.2019-03-19.16

\section{РЕКЛАМА ЯК РІЗНОВИД МАСОВОЇ КОМУНІКАЦІЇ}

\section{Арешенкова-Левченко О. Ю.}

к. філол. н.

КДПУ, Україна

Ключові слова: реклама, рекламна комунікація, рекламна інформація, рекламний текст.

Keywords: advertising, advertising communication, advertising information, advertising text.

Сучасна реклама - це дієвий інструмент впливу на адресата, здатний трансформувати, модифікувати світогляд, свідомість, поведінку людини. Основне завдання комерційної реклами - забезпечити попит на певні товари / послуги та максимально розширити кількість потенційних покупців. Ця прагматична настанова досягає успішного результату через комунікативну стратегію реклами: інформування, переконання, вплив і примус вибрати рекламований товар / послугу.

Жорсткі фінансові умови як один 3 екстралінгвальних чинників реклами вимагають максимальної компресії повідомлення, особливої щільності змісту, частина якого або не вербалізується, або символізується. Тому особливістю реклами є поєднання вербального блоку та невербальних компонентів: візуально-графічних (шрифт, колір, художні елементи, просторово-композиційні рішення, зображення, відеоряд), кінетичних (жест, поза, міміка) та аудіальних (інтонація, ритм, аудіочастини реклами).

Масове поширення інформативних повідомлень реклами дає підстави віднести ії до однієї з форм масової комунікації (Л. Антонова, Ф. Бацевич, С. Бибик, І. Білодід, І. Вікентьєв, С. Гузенко, Т. Джига, Т. Добросклонська, О. Зелінська, В. Зірка, С. Квіт, Н. Коваленко, М. Кохтєв, А. Лященко, О. Назайкін, Б. Обритько, А. Овчаренко, В. Різун, 